\title{
TNF-alpha 308 SNP Rs3091256 GG Genotype is Strongly Associated with Fibrosis in Patients with Chronic Hepatitis C
}

\section{TNF-alfa 308 SNP Rs3091256 GG Genotipi Hepatit C Virüs Hastalarının Karaciğer Fibrozis Evreleri ile llișkilidir}

\author{
Özgür GÜNAL ${ }^{1}$, Didem YALÇIN², Betül ÇELIK³, Aydın RÜSTEMOĞLU4ㄴ, Osman DEMIR5, \\ Şener BARUT6, Ömer ATEŞ4, Sırrı KILIÇ1
}

1 University of Health Science, Samsun Training and Research Hospital, Clinic of Infectious Diseases and Clinical Microbiology, Samsun, Turkey

2 University of Health Science, Antalya Training and Research Hospital, Clinic of Internal Medicine, Division of Allergy and Clinical Immunology Unit, Antalya, Turkey

3University of Health Science, Antalya Training and Research Hospital, Clinic of Pathology, Antalya, Turkey

${ }^{4}$ Gaziosmanpaşa University Faculty of Medicine, Department of Medical Biology, Tokat, Turkey

${ }^{5}$ Gaziosmanpaşa University Faculty of Medicine, Department of Biostatistics, Tokat, Turkey

${ }^{6}$ Gaziosmanpaşa University Faculty of Medicine, Department of Infectious Diseases and Clinical Microbiology, Tokat, Turkey

\begin{abstract}
Objective: We aimed to review the influence of host genetic factors on the clinical course, treatment response as well as fibrosis progression in patients with viral hepatitis $\mathrm{C}$ genotype 1.

Materials and Methods: Ninety-five patients with chronic hepatitis C virus $(\mathrm{HCV})$ infection and 97 controls were enrolled. The patients received pegylated interferon (Peg-IFN)+ribavirin therapy for 48 weeks and were followed up for the next 48 weeks. Aspartat aminotransferase/platelet ratio (APRI) was used to detect liver fibrosis DNA specimens were extracted from the peripheral blood mononuclear cells and the tumor necrosis factor-alpha (TNF- $\alpha$ ) 308 rs3091256 was genotyped by the polymerase chain reactionrestriction fragment length polymorphism method.

Results: All patients included in the study were infected with HCV genotype 1. of the $95 \mathrm{HCV}$-positive patients, spontaneous viral clearence was observed in $25.5 \%$, rapid viral response in $44.2 \%$, early viral response in $91.8 \%$, and sustained viral response was found in $73.3 \%$ of patients. The allele and genotype were not significant between patients and controls. There was no significant difference in virologic response as well. However, TNF- $\alpha-308$ single nucleotide polymorphisms (SNP) rs3091256 GG genotype was strongly associated with fibrosis and alanine aminotransferase (ALT) levels ( $p=0.006$ and $p=0.017$, respectively).

Conclusion: TNF- $\alpha-308$ polymorphisms may reveal different results among countries. Patients having SNP rs3091256 GG are prone to have higher ALT levels and fibrosis score but have better treatment outcome. Keywords: Hepatitis C, tumor necrosis factor alpha, polymorphisms, interferon, treatment
\end{abstract}

OZZ

Amaç: Viral hepatit $\mathrm{C}$ genotip 1 hastalarında genetik faktörlerin klinik gidiș, tedavi cevabı ve fibrozis ilerlemesi üzerindeki etkisini gözden geçirmektir.

Gereç ve Yöntemler: Çalışmaya 95 kronik hepatit $C$ virüs $(\mathrm{HCV})$ hastası ve 97 sağlıklı gönüllü dahil edildi. Hastalar 48 hafta süreyle pegylated interferon (Peg-IFN)+ribavirin tedavisi kullandı ve sonraki 48 hafta boyunca takip edildi. Karaciğer fibrozis evresini belirlemek için aspartat aminotransferaz/platelet ratio (APRI) kullanıldı. DNA örnekleri periferik kan mononükleer hücrelerden izole edildi ve tümör nekroz faktörü-alfa (TNF- $\alpha) 308$ rs3091256, polimeraz zincir reaksiyonu-kısıtlama fragmanı uzunluğu polimorfizmi yöntemi ile genotiplendi.

Bulgular: Tüm hastalar HCV genotip 1 ile enfekte idi. HCV hastalarının (95), \%25,5 spontan viral klirensi, \%44,2'si hızlı viral yanıt, \%91,8'i erken viral yanıt ve \%73,3'ünde kalıcı viral yanıt gözlendi. Hastalar ve kontroller arasında allel ve genotip açısından anlamlı fark yoktu. Virolojik yanıt da belirgin değildi. Bununla birlikte, TNF- $\alpha$-308 tek nükleotit polimorfizmi (SNP) rs3091256 GG genotipi fibroz ve alanin aminotransferaz (ALT) seviyeleri ile kuvvetli bir şekilde ilişkiliydi (sırasıyla $p=0,006$ ve $p=0,017$ ).

Sonuç: TNF- $\alpha$-308 polimorfizmleri, ülkeler arasında farklı sonuçlar ortaya çıkarabilir. SNP rs3091256 GG'ye sahip hastalar, daha yüksek ALT ve fibroz skoru göstermekle birlikte, bu popülasyonda daha iyi tedavi sonucuna sahiptir.

Anahtar Kelimeler: Hepatit C, tümör nekroz faktörü-alfa, polimorfizm, interferon, tedavi

Günal 0̈, Yalçın D, Çelik B, Rüstemoğlu A, Demir O, Barut Ş, Ateş Ö, Kılıç S. TNF-alpha 308 SNP Rs3091256 GG Genotype is Strongly Associated with Fibrosis in Patients with Chronic Hepatitis C. Viral Hepat J. 2017;23:39-45. 


\section{Introduction}

Hepatitis C virus $(\mathrm{HCV})$ is a major etiologic factor for the development of chronic liver diseases (cirrhosis, hepatocellular carcinoma, etc.). Hepatocytes are the primary target cells supporting $\mathrm{HCV}$ replication. After HCV infection, the innate immune system begins to respond to the virus and after 4 to 8 weeks, the CD8 + T cells recognize viral peptides that bind to human leukocyte antigen class I molecules in virus-infected hepatocytes (1).

This initiates signaling pathways leading to the synthesis of interferon (IFN), tumor necrosis factor (TNF) and a variety of other cytokines. In the acute phase of the infection, the virus is removed from the T-cell-mediated antiviral mechanisms. The rate of spontaneous viral clearance in acut HCV infection is aproximately $26 \%$ (range: $15-40 \%)(2,3,4,5)$. In patients who cannot clear the virus from hepatocytes in the first phase, $\mathrm{HCV}$ remains for years as long as it is not being treated. The effective treatment of chronic $\mathrm{HCV}$ infection $(\mathrm{CHC})$ is based on a combination of pegylated-IFN (Peg-IFN) and ribavirin (RBV) (6). IFN, especially IFN- $\lambda 3$, interacts with its acceptor, a heterodimer (IFN-lambdaR1 x IL-10R2). In IFNbased treatments, sustained viral response (SVR) rate is $40 \%(2,7)$.

The most important parameter in the therapeutic success in $\mathrm{HCV}$ infection is based on the HCV genotype (e.g., genotype 1 is the most difficult to treat) (2). In IFN-based treatments in the genotype 2, 3 and 5, the rate of SVR is 70-90\% while in genotype 1 and 4 , it is not more than $50 \%(1,8)$. HCV genotype 1 (91.8\%) was the most common genotype in multicentre studie performed by Gürbüz et al. (9) in our country, while genotype 2 (4\%) was detected in the second frequency.

Besides HCV genotype, serum alanine aminotransferase (ALT) level, histological grading and cytokine response of the host may affect HCV infection, viral clearance, and treatment $(10,11)$. Among the cytokines, the most attention was devoted to TNF-alpha (TNF- $\alpha$ ). Serum TNF- $\alpha$ level elevates in $\mathrm{CHC}$ patients (12) and SVR has been found to be associated with the baseline increased production of TNF- $\alpha$ (11). A positive correlation has been found between serum TNF- $\alpha$ levels and hepatic necroinflammatory score as well (13).

It was demonstrated that $\mathrm{HCV}$ can directly induce the expression of TNF- $\alpha$ in hepatocytes (14). Induction of TNF- $\alpha$ by $\mathrm{HCV}$ is dependent on Toll-like receptor (TLR) 7 and TLR8. Form recognition receptors seen in many cell types that participate in the innate immune response associated with viral infections and viral antigens are called TLRs (15). TNF binds to two receptors, TNFR1 and TNFR2; the first is structurally expressed in most cells, the second is inducible and has a more limited expression pattern (16). Upon receptor binding, TNF- $\alpha$ signals through a variety of cytosolic proteins, including TRADD (TNFR1-associated death domain protein) (17) and TNF receptor-associated factor 2 (18), leading to I_B degradation and the subsequent release and nuclear translocation of nuclear factor (NF)-kB. Binding of NF-kB to gene promoters initiates transcription of numerous proinflammatory cytokines, including TNF- $\alpha$, IL-6, IL-8, and CXCL-10 $(19,20)$ which suppress HCV replication.

The present study was designed to investigate the frequency of single-nucleotide polymorphism (SNP) of the TNF-308 locus in a population in Turkey, a region with a high prevalence of $\mathrm{HCV}$ infection. High prevalence of genotype $1 \mathrm{~b}$ is more likely associated with fibrosing score, ALT level, spontaneous viral clearance and efficacy of treatment of HCV genotype 1.

\section{Materials and Methods}

A total of 95 anti-HCV-positive genotype $1 \mathrm{~b}$ and 2 patients (70 HCV RNA+ chronic active hepatitis and 25 HCV RNA-negative and spontaneous clearance) and 97 healthy control subjects (57 female, 40 male) were included in the study. The Ethics Committee of Gaziosmanpaşa University approved the present study and all participants provided written informed consent for the study (Grant number: 11-BADK-111).

Genomic DNA was extracted from blood samples using an Invitrogen Genomic DNA Isolation Mini Kit K1820-02 (Invitrogen Life Technologies, Carlsbad, CA, USA). Polymerase chain reaction (PCR) was performed in a total volume of $25 \mu \mathrm{L}$, using $100 \mathrm{ng}$ genomic DNA with 20 pmol each primers, $0.2 \mathrm{mM}$ each dNTP, 1X buffer, $2 \mathrm{mM} \mathrm{MgCl}_{2}$ and $1 \mathrm{U}$ Taq DNA polymerase (Invitrogen Life Technologies, Carlsbad, CA, USA). Cycling was performed in a techne TC-4000 thermal cycler (Bibby Scientific Limited, Staffordshire, UK) as follows: amplification consisted of a 2-minute denaturation step at $96{ }^{\circ} \mathrm{C}$; 35 cycles of one minute at $94{ }^{\circ} \mathrm{C}$, one minute at $60{ }^{\circ} \mathrm{C}$, one minute at $72{ }^{\circ} \mathrm{C}$ and final extension of 7 minutes at $72{ }^{\circ} \mathrm{C}$ followed by cooling to $4{ }^{\circ} \mathrm{C}$.

Genotype analysis of TNF- $\alpha-308$ (rs3091256) polymorphism was performed using restriction fragment length polymorphism. PCR products were digested with Nco1 restriction enzyme. The digested PCR products were resolved by electrophoresis on $2.5 \%$ agarose gels containing $0.5 \mu \mathrm{g} / \mathrm{mL}$ ethidium bromide. Restriction fragments were visualized with the use of a Vilber-Lourmat Gel Quantification and Documentation System QUANTUM-ST4 (Vilber Lourmat BP 66 Torcy, France). Aspartate aminotransferase/platelet ratio index (APRI) was used to determine liver fibrosis stage.

\section{Statistical Analysis}

Descriptive analyses were performed to provide information on general characteristics of the study population. Independent samples t-test was used to compare the continuous data between the groups. The continuous data were presented as mean \pm standard deviation. Chi-square test was used to compare the categorical data between/among groups. Categorical variables were presented as a count and percentage. A p-value of less than 0.05 was considered statistically significant. Analyses were performed using SPSS 19 (IBM SPSS Statistics 19, SPSS Inc., IBM Co., Somers, NY).

\section{Results}

Ninety-five patients (62 female, 33 male) received Peg-IFN+RBV for 48 weeks and followed up for the next 48 weeks. APRI was used to determine liver fibrosis stage. There was no significant difference between the patient and the control groups in terms of age, gender and viral genotype. Clinical variables are given in Table 1. There was no statistically significant difference between $\mathrm{CHC}$ patients and healthy controls in terms of TNF- $\alpha-308$ (rs3091256) polymorphism genotype distribution ( $p=0.362$, Table 2). On the other hand, ALT values were found to be higher in $\mathrm{CHC}$ patients with TNF- $\alpha-308$ GG polymorphism compared to $\mathrm{CHC}$ patients with $G A+A A$ polymorphism ( $p=0.017)$. Moreover, $A P R I$ score was 


\begin{tabular}{|c|c|c|}
\hline \multicolumn{2}{|l|}{ Variables } & \multirow{2}{*}{\begin{tabular}{|l|} 
Statistics \\
70 (73.7) \\
\end{tabular}} \\
\hline \multirow[b]{2}{*}{ Patients } & Active hepatitis & \\
\hline & $\begin{array}{l}\text { Spontaneous } \\
\text { clearence }\end{array}$ & $25(26.3)$ \\
\hline \multirow{2}{*}{ RVY } & hvy + & $27(42.2)$ \\
\hline & hvy - & $37(57.8)$ \\
\hline \multirow{2}{*}{ EVY } & evy + & $58(90.6)$ \\
\hline & evy - & $6(9.4)$ \\
\hline \multirow{2}{*}{$\begin{array}{l}\text { Primary } \\
\text { Non-responder }\end{array}$} & yes & $6(9.4)$ \\
\hline & no & $58(90.6)$ \\
\hline \multirow{2}{*}{ Relaps } & yes & $15(23.4)$ \\
\hline & no & 49 (76.6) \\
\hline \multirow{2}{*}{ SVR } & yes & $46(71.9)$ \\
\hline & no & $18(28.1)$ \\
\hline \multirow{2}{*}{ Sex } & female & $63(63.6)$ \\
\hline & male & $36(36.4)$ \\
\hline \multirow{3}{*}{ Treatment } & IFN- $\alpha$ & $35(47.3)$ \\
\hline & IFN- $\beta$ & $29(39.2)$ \\
\hline & No treatment & $10(13.5)$ \\
\hline \multirow{3}{*}{ TNF } & GG & $78(82.1)$ \\
\hline & GA & $14(14.7)$ \\
\hline & AA & $3(3.2)$ \\
\hline \multirow{2}{*}{ TNF_Gene } & GG & $78(82.1)$ \\
\hline & $\mathrm{GA}+\mathrm{AA}$ & $17(17.9)$ \\
\hline \multirow{3}{*}{ IL28B860 } & $\mathrm{CC}$ & $23(23.2)$ \\
\hline & СT & $58(58.6)$ \\
\hline & TT & $18(18.2)$ \\
\hline \multirow{3}{*}{ IL28B275 } & GG & $18(18.6)$ \\
\hline & GA & $53(54.6)$ \\
\hline & AA & $26(26.8)$ \\
\hline \multirow{3}{*}{ IL28B917 } & GG & $10(10.1)$ \\
\hline & GT & $49(49.5)$ \\
\hline & $\mathrm{TT}$ & $40(40.4)$ \\
\hline \multirow{2}{*}{ CCR5 } & $\mathrm{NN}$ & $93(93.9)$ \\
\hline & ND & $6(6.1)$ \\
\hline \multirow{2}{*}{ APRI score } & $0-0.49$ & $43(58.1)$ \\
\hline & $0.50+$ & $31(41.9)$ \\
\hline \multirow{3}{*}{ APRI score } & 0.0 & $27(36.5)$ \\
\hline & No fibrosis & $44(59.5)$ \\
\hline & Extensiv fibrosis & $3(4.1)$ \\
\hline Age & & $55.91 \pm 9.84$ \\
\hline HCV RNA & & $784.545 \pm 1345.413$ \\
\hline HAI (ISHAK) & & $9.04 \pm 3.33$ \\
\hline Fibrosing score (ISHAK) & & $1.83 \pm 1.05$ \\
\hline WBC & & $6357.87 \pm 2192.49$ \\
\hline $\mathrm{HB}$ & & $12.98 \pm 1.61$ \\
\hline PLT & & $220.29 \pm 69.81$ \\
\hline
\end{tabular}

\begin{tabular}{|c|c|}
\hline Variables & Statistics \\
\hline AST & $38.7 \pm 28.07$ \\
\hline ALT & $44.85 \pm 42.02$ \\
\hline APRI & $0.56 \pm 0.42$ \\
\hline \multicolumn{2}{|c|}{$\begin{array}{l}\text { Used to } \mathrm{n}(\%) \text { for qualitative variables and mean } \pm \text { standard deviation for } \\
\text { quantitative variables } \\
\text { RVY: Rapid virologycal response, EVY: Early virologic reponse, SVR: Sustained } \\
\text { virologic response, APRI: Aspartate aminotransferase to platelet ratio index, } \\
\text { ALT: Alanine aminotransferase, AST: Aspartate aminotransferase, TNF: Tumor } \\
\text { necrosis factor, HAI: Hepatic activity index, WBC: White blood cells, HB: } \\
\text { Hemoglobin, PLT: Platelets, HCV: Hepatitis C virus IFN- } \alpha \text { : Interferon alpha, IFN- } \\
\text { B: Interferon beta }\end{array}$} \\
\hline
\end{tabular}

found to be significantly higher in $\mathrm{CHC}$ patients with TNF- $\alpha-308$ GG polymorphism compared to those with $\mathrm{GA}+\mathrm{AA}$ polymorphism $(\mathrm{p}=0.006)$ (Table 3).

To evaluate the clinical applicability of the outlined SNP, we calculated the predictive odds ratios for the SNP between rapid virological response (RVR), early virological response (EVR) and SVR (Table 4). There were 24 patients who had spontaneous viral clearance. RVR was seen in 27 patients. EVR in 56 patients and SVR was observed in 44 patients. All the genotypes or alleles predicted the positive response to treatment in the overall study population.

\section{Discussion}

HCV infection continues to be a major health problem worldwide. Viruses are the most common cause of diseases such as chronic hepatitis and liver cirrhosis. HCV is divided into seven major genotypes (21). After infection with $\mathrm{HCV}$, a large proportion of patients develop $\mathrm{CHC}$, with a very few spontaneous clearance. (6). There are viral and host factors that are important in the development of chronic infection. Baseline viral load, RVR and host characteristics (e.g. alcohol consumption, steatosis, liver fibrosis, metabolic syndrome, ethnicity, and host genetic polymorphisms, especially IL28B, are the examples that have impact on virological response of the host (2). The most common HCV genotype worldwide is genotype 1 (46\% of all HCV cases), while genotype 3 is the second most common (30\%). However, the distribution of these genotypes varies between countries (22).

The first target for HCV is human hepatocytes. The immune system first activates the natural immune system. As a result, local IFN production begins and HCV genome replication and spreading in the liver parenchyma is disrupted (23). The mechanism of effective clearance of HCV from the human body is likely related to both environmental and host genetic factors. For example, it has been observed that treatment success in patients of European ancestry is better than in patients of African ancestry (24). In the current study, we performed an analysis to examine the association between the SNP in the promoter region of TNF- $\alpha-308$ rs3091256 and fibrosis score, ALT level, spontaneous viral clearance and treatment response to $\mathrm{HCV}$ infection.

There are varying results from studies on TNF- $\alpha-308$ gene polymorphism in the literature. Although some studies have reported a significant association between TNF polymorphism and response to hepatitis $\mathrm{C}$ treatment, some studies reported 
the opposite. In their study, Dai et al. (24) from Taiwan suggested that TNF polymorphism at position-308 may be a predictor of treatment failure in patients treated with a combination of IFN- $\alpha$ and RBV and in another study from Brazil, the TNF- $\alpha-308$ a allele was found to be a predictor of null virological response $(25,26)$, but other investigations have failed to confirm such findings. An Egyptian study found that at the TNF- $\alpha 308$ position, the G/G allele was most common (78.5\%) in the study population compared to controls (27).

In this study, no significant difference was observed in the frequency of the TNF $\alpha$-308 (rs3091256) polymorphism. Our results are consistent with those reported by Barrett et al. (28) who did not find the SNP at 308 to be associated with viral recovery or persistence. In studies conducted in different countries, there was

\begin{tabular}{|c|c|c|c|c|c|c|}
\hline Genotype/allele & Patients (95) & $p$ for HWE & Control (97) & $p$ for HWE & $\mathrm{p}$ & $\mathrm{OR}$ \\
\hline GG & $78(0.8210)$ & \multirow{3}{*}{0.0339} & $82(0.8454)$ & \multirow{3}{*}{0.492} & 0.701 & $0.84(0.39-1.79)$ \\
\hline AA & $3(0.0316)$ & & 0 & & 0.119 & $7.38(0.38-142.61)$ \\
\hline G & $170(0.8947)$ & & $179(0.9227)$ & & 0.378 & $0.71(0.35-1.43)$ \\
\hline
\end{tabular}

\begin{tabular}{|c|c|c|c|c|}
\hline \multirow{2}{*}{\multicolumn{2}{|c|}{ Variables }} & \multicolumn{2}{|c|}{ TNF } & \multirow{2}{*}{$\mathrm{p}$} \\
\hline & & $\mathrm{GA}+\mathrm{AA}$ & GG & \\
\hline Non-responder & No & $47(92.2)$ & $9(81.8)$ & $0.287^{a}$ \\
\hline Relapse & Yes & $12(23.5)$ & $2(18.2)$ & $0.525^{\mathrm{a}}$ \\
\hline SVR & No & $14(27.5)$ & $3(27.3)$ & $0.652^{a}$ \\
\hline \multicolumn{2}{|l|}{ APRI } & $0.61 \pm 0.46(n=58)$ & $0.39 \pm 0.17(n=13)$ & $0.006^{b}$ \\
\hline \multicolumn{2}{|l|}{ ALT } & $47.90 \pm 45.53(n=78)$ & $31.29 \pm 18.27(n=17)$ & $0.017^{b}$ \\
\hline
\end{tabular}

\begin{tabular}{|c|c|c|c|c|c|c|}
\hline & & \multicolumn{3}{|c|}{ Genotypes } & \multicolumn{2}{|c|}{ Alleles } \\
\hline & & AA & G & A & GG & GA \\
\hline Patients & $\mathrm{CHC}(n=70)$ & $58(82.86 \%)$ & $10(14.29 \%)$ & $2(2.86 \%)$ & $126(90.00 \%)$ & $14(10.00 \%)$ \\
\hline \multicolumn{2}{|l|}{$p$} & 1.000 & 1.000 & 1.000 & 1.000 & \\
\hline \multicolumn{2}{|c|}{$\mathrm{OR}, 95 \% \mathrm{Cl}$} & $0.97,0.29-3.27$ & $1.17,0.30-4.54$ & $0.68,0.06-7.50$ & $1.05,0.36-3.05$ & \\
\hline \multirow[t]{2}{*}{ RVR } & Yes (27) & 25 (92.59\%) & $2(7.41 \%)$ & 0 & $52(96.30 \%)$ & $2(3.70 \%)$ \\
\hline & No (34) & $26(76.47 \%)$ & $7(20.59 \%)$ & $1(2.94 \%)$ & $59(86.76 \%)$ & $9(13.24 \%)$ \\
\hline \multicolumn{2}{|l|}{$p$} & 0.162 & 0.276 & 1.000 & 0.110 & \\
\hline \multicolumn{2}{|c|}{$\mathrm{OR}, 95 \% \mathrm{Cl}$} & $3.85,0.77-19.33$ & $0.31,0.06-1.58$ & $0.41,0.02-9.81$ & $3.97,0.83-18.9$ & \\
\hline \multirow[t]{2}{*}{ EVR } & Yes (56) & 47 (83.93\%) & $8(14.29 \%)$ & $1(1.79 \%)$ & $102(91.07 \%)$ & $10(8.93 \%)$ \\
\hline & No (5) & $4(80.00 \%)$ & $1(20.00 \%)$ & 0 & $9(90.00 \%)$ & $1(10.00 \%)$ \\
\hline \multicolumn{2}{|l|}{$\mathrm{p}$} & 1.000 & 0.563 & 1.000 & 1.000 & \\
\hline \multicolumn{2}{|c|}{$\mathrm{OR}, 95 \% \mathrm{Cl}$} & $1.31,0.16-10.49$ & $0.67,0.08-5.42$ & $0.30,0.01-6.56$ & $1.13,0.14-8.93$ & \\
\hline \multirow[t]{2}{*}{ SVR } & Yes (44) & $36(81.82 \%)$ & $7(15.91 \%)$ & $1(2.27 \%)$ & 79 (89.77\%) & $9(10.23 \%)$ \\
\hline & No (16) & $14(87.50 \%)$ & $2(12.50 \%)$ & 0 & $30(93.75 \%)$ & $2(6.25 \%)$ \\
\hline \multicolumn{2}{|l|}{$\mathrm{p}$} & 0.715 & 1.000 & 1.000 & 0.725 & \\
\hline \multicolumn{2}{|c|}{$\mathrm{OR}, 95 \% \mathrm{Cl}$} & $0.64,0.13-3.26$ & $1.32,0.26-6.84$ & $1.14,0.05-27.06$ & $0.59,0.12-2.80$ & \\
\hline
\end{tabular}


no correlation between TNF gene polymorphisms and histological severity or response to antiviral treatment (29). In a meta-analysis of studies performed at different centers, it has been shown that there is no significant association between TNF- $\alpha-308,-238$ gene polymorphisms and susceptibility to infection among different HCV subgroups. (30). Besides, the distributions of TNF- $\alpha-308,-238$ A/G alleles were also not significantly different between the persistent infection group and the spontaneous clearance group. It is well known that certain diseases such as psoriasis and concomitant HCV infection are succesfully treated with anti-TNF therapy without signs of reactivation of HCV $(31,32)$. Therefore, we conclude that TNF- $\alpha$-308 (rs3091256) polymorphism may not really have any effect on treatment response.

TNF- $\alpha$ may affect hepatic fibrogenesis by stimulating hepatic stellate cells (33). After TNF- $\alpha$ activation, Kupffer cells secrete TGF-beta1, an important fibrogenic molecule. The relationship between cirrhosis development and TNF promoter has been investigated extensively $(34,35,36,37)$. Although Romero-Gómez et al. (38) found no association between polymorphism in -308 and the severity of fibrosis in HCV and Abdel-Latif found (11) in both fibrotic and cirrhotic cases, no significant correlation was observed in levels of matrix metalloproteinases (MMP)-2, MMP-9, and TNF- $\alpha$ between fibrotic and cirrhotic cases (39). TNF- $\alpha$ has been found higher in cirrhotic patients compared to $\mathrm{CHC}$ patients with no or mild fibrosis (40). Consistent with these results, our study also confirmed the association between TNF- $\alpha-308$ GG polymorphism and fibrosis score $(\mathrm{p}=0.006)$. This may be explained by higher constitutive and inducible transcriptional activity of TNF. Nevertheless, in a meta-analysis of 11 different studies, no association was found between TNF- $\alpha-308 \mathrm{G}>\mathrm{A}$ polymorphism and liver cirrhosis risk in both Caucasians and Asian populations (41).

No correlation has been shown between 308 promoter polymorphisms and necroinflammatory histological activity. Although one study compared ALT levels between SVR patients and non-responders and found no statistically significant difference (10), the other found a statistically significant difference between healthy controls and those with cirrhosis and hepatocellular carcinoma (30), these studies did not include TNF polymorphism. Abbas et al. (41) studied HCV genotype 3 and found no association between ALT level and TNF- $\alpha-308$ polymorphism. Besides, only $5 \%$ of their patients had TNF- $\alpha-308$ GG promoter. In our study, we found a statistically significant relationship between TNFa-308 GG polymorphism and high ALT levels in HCV genotype 1 patients ( $p=0.017)$ and although not statistically significant, $73.3 \%$ of our study population had SVR. In a study from Turkey, liver infiltrating lymphomononuclear cells were stimulated with TNF- $\alpha$ and histology activity index and HCV genotype revealed a negative correlation between TNF- $\alpha$ levels and elevated ALT levels in patients infected with $1 \mathrm{~b}(42)$.

After circulating HCV particles reach the basolateral surfaces of hepatocytes, where the virus first binds to several receptors, the virus attaches to hepatocytes, it fuses the membrane and enters the cytosol and starts to replicate (43). Liver damage from HCV depends on both host's immune system-mediated reactions and viral cytopathic effects (44). The CD95 frequency was significantly higher in $\mathrm{HCV}$ antigen-positive hepatocytes compared to uninfected cells (45). TNF might play a role in hepatic necrosis and inflammation. Serum ALT level correlates with liver damage and we here propose that elevated ALT levels is the hallmark of hepatocyte injury eventully leading to fibrosis as well as elimination of virus in $\mathrm{CHC}$ (the more inflammation, the more viral eradication) (46).

\section{Study Limitations}

The study was conducted before the start of the use of new treatments.

\section{Conclusion}

In conclusion, this is the first article in which ALT level and liver fibrosis are associated with TNF- $\alpha-308$ GG polymorphism treated with IFN. The discrepancies in TNF genetic polymorphism and treatment responses among studies may be due to differences between ethnic groups.

\section{Ethics}

Ethics Committee Approval: The Ethics Committee of Gaziosmanpaşa University approved the present study (approval number: 11-BADK-111).

Informed Consent: Informed consent forms were obtained from all the patients who participated in the study.

Peer-review: Internally peer-reviewed.

\section{Authorship Contributions}

Surgical and Medical Practise: Ö.G., A.R., Ö.A., S..B., Concept: Ö.G., D.Y., B.C.., Desing: Ö.G., D.Y., B.C.., Data Collection or Processing: Ö.G., A.R., Analysis: O.D., S.K., Literature Search: Ö.G., D.Y., B.C.., Ö.T., Writing: Ö.G., D.Y., B.Ç.

Conflict of Interest: No conflict of interest was declared by the authors.

Financial Disclosure: The funding for this study was provided by Gaziosmanpaşa University (Grant number: 11-BADK-111).

\section{References}

1. Cybula M, Szemraj J. The role of hepcidin and polymorphisms in the regulatory region of the IL-28B gene in HCV infections. Postepy Hig Med Dosw (Online). 2013;67:1273-1282.

2. Buti M, Esteban R. Hepatitis C virus genotype 3: a genotype that is not 'easy-to-treat'. Expert Rev Gastroenterol Hepatol. 2015:9:375-385.

3. Di Bisceglie AM. Natural history of hepatitis C: its impact on clinical management. Hepatology. 2000;31:1014-1018.

4. Gerlach JT, Diepolder HM, Zachoval R, Gruener NH, Jung MC, Ulsenheimer A, Schraut WW, Schirren CA, Waechtler M, Backmund M, Pape GR. Acute hepatitis $C$ : high rate of both spontaneous and treatment-induced viral clearance. Gastroenterology. 2003;125:80-88.

5. Micallef JM, Kaldor JM, Dore GJ. Spontaneous viral clearance following acute hepatitis C infection: a systematic review of longitudinal studies. J Viral Hepat. 2006;13:34-41.

6. Saito T, Ueno Y. Transmission of hepatitis C virus: selflimiting hepatitis or chronic hepatitis? World J Gastroenterol. 2013; 19:6957-6961

7. Manns MP, Wedemeyer $\mathrm{H}$, Cornberg M. Treating viral hepatitis $\mathrm{C}$ : efficacy, side effects, and complications. Gut. 2006;55:1350-1359.

8. Stättermayer AF, Ferenci P. Effect of IL28B genotype on hepatitis $B$ and $C$ virus infection. Curr Opin Virol. 2015;14:50-55. 
9. Gürbüz Y, Tülek NE, Tütüncü EE, Koruk ST, Aygen B, Demirtürk N. et al. Evaluation of Dual Therapy in Real Life Setting in TreatmentNaïve Turkish Patients with HCVInfection: A Multicenter Retrospective Study. Balkan Med J. 2016 Jan;33(1):18-26.

10. Par G, Szereday L, Berki T, Palinkas L, Halasz M, Miseta A, Hegedus G, Szekeres-Bartho J, Vincze A, Hunyady B, Par A. Increased baseline proinflammatory cytokine production in chronic hepatitis $\mathrm{C}$ patients with rapid virological response to peginterferon plus ribavirin. PLoS One. 2013;8:e67770.

11. Abdel-Latif MS. Plasma Levels of Matrix Metalloproteinase (MMP)-2, MMP-9 and Tumor Necrosis Factor- $\alpha$ in Chronic Hepatitis C Virus Patients. Open Microbiol J. 2015;9:136-140.

12. Walsh KM, Timms P, Campbell S, MacSween RN, Morris AJ. Plasma levels of matrix metalloproteinase-2 (MMP-2) and tissue inhibitors of metalloproteinases-1 and-2 (TIMP-1 and TIMP-2) as noninvasive markers of liver disease inchronic hepatitis C: comparison using ROC analysis. Dig Dis Sci. 1999;44:624-630.

13. Lee J, Tian Y, Chan ST, Kim JY, Cho C, Ou JH. TNF- $\alpha$ Induced by Hepatitis C Virus via TLR7 and TLR8 in Hepatocytes Supports Interferon Signaling via an Autocrine Mechanism. PLoS Pathog. 2015;11:e1004937.

14. Mogensen TH. Pathogen recognition and inflammatory signaling in innate immune defenses. Clin Microbiol Rev. 2009;22:240-273.

15. Puimège $L$, Van Hauwermeiren $F$, Steeland $S$, Van Ryckeghem S, Vandewalle J, Lodens S, Dejager L, Vandevyver S, Staelens J, Timmermans S, Vandenbroucke RE, Libert C. Glucocorticoidinduced microRNA-511 protects against TNF by down-regulating TNFR1. EMBO Mol Med. 2015;7:1004-1017.

16. Jones SJ, Ledgerwood EC, Prins JB, Galbraith J, Johnson DR, Pober JS, Bradley J. TNF recruits TRADD to the plasma membrane but not the trans-Golgi network, the principal subcellular location of TNF-R1. J Immunol. 1999;162:1042-1048.

17. Takeuchi M, Rothe M, Goeddel DV. Anatomy of TRAF2. Distinct domains for nuclear factor-kappaB activation and association with tumor necrosis factor signaling proteins. J Biol Chem. 1996;271:19935-19942.

18. Yang J, Lin Y, Guo Z, Cheng J, Huang J, Deng L, Liao W, Chen Z, Liu Z, Su B. The essential role of MEKK3 in TNF-induced NF-kB activation. Nat Immunol. 2001;2:620-624.

19. Blonska M, Shambharkar PB. Kobayashi M, Zhang D, Sakurai $H$, Su B, Lin X. TAK1 is recruited to the tumor necrosis factor- $\alpha$ (TNF- $\alpha$ ) receptor 1 complex in a receptor-interacting protein (RIP)dependent manner and cooperates with MEKK3 leading to NF-кB activation. J Biol Chem. 2005;280:43056-43063.

20. Smith DB, Bukh J, Kuiken C, Muerhoff AS, Rice CM, Stapleton JT, Simmonds P. Expanded classification of hepatitis $C$ virus into 7 genotypes and 67 subtypes: updated criteria and genotype assignment web resource. Hepatology. 2014;59:318-327.

21. Venegas M, Brahm J, Villanueva RA. Genomic determinants of hepatitis $C$ virus antiviral therapy outcomes: toward individualized treatment. Ann Hepatol. 2012;11:827-837.

22. Horner SM, Gale M Jr. Regulation of hepatic innate immunity by hepatitis C virus. Nat Med. 2013;19:879-888.

23. Kanwal F, White DL, Tavakoli-Tabasi S, Jiao L, Lin D, Ramsey DJ, Spiegelman A, Kuzniarek J, El-Serag HB. Many patients with interleukin $28 \mathrm{~B}$ genotypes associated with response to therapy are ineligible for treatment because of comorbidities. Clin Gastroenterol Hepatol. 2014;12:327-333.

24. Dai CY, Chuang WL, Chang WY, Chen SC, Lee LP, Hsieh MY, Hou NJ, Lin ZY, Huang JF, Hsieh MY, Wang LY, Yu ML. Tumor necrosis factor-alpha promoter polymorphism at position -308 predicts response to combination therapy in hepatitis $\mathrm{C}$ virus infection. $\mathrm{J}$ Infect Dis. 2006;193:98-101.

25. Grandi T, Silva CM, Amaral KM, Picon PD, Costi C, Fré NN Fiegenbaum M, Gregianini TS, Niel C, Rossetti ML. Tumour necrosis factor 308 and-238 promoter polymorphisms are predictors ofa null virological response in the treatment of Brazilian hepatitis C patients. Mem Inst Oswaldo Cruz. 2014;109:345-351.

26. Brinkman BM, Zuijdgeest D, Kaijzel EL, Breedveld FC, Verweij $\mathrm{CL}$. Relevance of the tumor necrosis factor alpha (TNF $\alpha)-308$ promoter polymorphism in TNF $\alpha$ gene regulation. J Inflamm. 1996:46:32-41.

27. Talaat RM, Esmail AA, Elwakil R, Gurgis AA, Nasr MI. Tumor necrosis factor-alpha $-308 \mathrm{G} / \mathrm{A}$ polymorphism and risk of hepatocellular carcinoma in hepatitis $C$ virus-infected patients. Chin J Cancer. 2012;31:29-35.

28. Barrett S, Collins M, Kenny C, Ryan E, Keane CO, Crowe J. Polymorphisms in tumor necrosis factor-alpha, transforming growth factor beta, interleukin-10, interleukin-6, interferongamma, and outcome of hepatitis C virus infection. J Med Virol. 2003;71:212-218

29. Höhler T, Kruger A, Gerken G, Schneider PM, Meyer zum Büschenfelde $\mathrm{KH}$, Rittner $\mathrm{C}$. Tumor necrosis factor alpha promoter polymorphism at position-238 is associated with chronic active hepatitis C. J Med Virol. 1998;54:173-177.

30. Amini $M$, Poustchi $H$. Hepatitis $C$ virus spontaneous clearance: immunology and genetic variance. Viral Immunol. 2012;25:241248.

31. He J, Pei X, Xu W, Wang C, Zhang X, Wu J, Zhao W. The relationship between tumor necrosis factor- $\alpha$ polymorphisms and hepatitis $\mathrm{C}$ virus infection: a systematic review and meta-analysis. Ren Fail. 2011;33:915-922.

32. Salvi M, Macaluso L, Luci C, Mattozzi C, Paolino G, Aprea Y, Calvieri S, Richetta AG. Safety and efficacy of anti-tumor necrosis factors $\alpha$ in patients with psoriasis and chronic hepatitis C. World J Clin Cases. 2016;4:49-55.

33. Friedman SL. Molecular mechanisms of hepatic fibrosis and principles of therapy. J Gastroenterol. 1997:32:424-430.

34. Bataller R, North KE, Brenner DA. Genetic polymorphisms and the progression of liver fibrosis: a critical appraisal. Hepatology. 2003;37:493-503

35. Yee LJ, Tang J, Herrera J, Kaslow RA, van Leeuwen DJ. Tumor necrosis factor gene polymorphisms in patients with cirrhosis from chronic hepatitis C virus infection. Genes Immun. 2000;1:386-390

36. Radwan MI, Pasha HF, Mohamed RH, Hussien HI, El-Khshab MN. Influence of transforming growth factor-b1 and tumor necrosis factor-a genes polymorphisms on the development of cirrhosis and hepatocellular carcinoma in chronic hepatitis C patients. Cytokine. 2012;60:271-276.

37. Dai CY, Chuang WL, Lee LP, Chen SC, Hou NJ, Lin ZY, Hsieh MY, Hsieh MY, Wang LY, Chang WY, Yu ML. Associations of tumour necrosis factor alpha promoter polymorphisms at position -308 and -238 with clinical characteristics of chronic hepatitis C. J Viral Hepat. 2006;13:770-774.

38. Romero-Gómez M, Montes-Cano MA, Otero-Fernández MA Torres B, Sánchez-Muñoz D, Aguilar F, Barroso N, Gómez-Izquierdo L, Castellano-Megias VM, Núñez-Roldán A, Aguilar-Reina J, González-Escribano MF. SLC11A1 promoter gene polymorphisms and fibrosis progression in chronic hepatitis C. Gut. 2004;53:446450.

39. Andersen ES, Ruhwald M, Moessner B, Christensen PB, Andersen $\mathrm{O}$, Eugen-Olsen J, Weis N. Twelve potential fibrosis markers to differentiate mild liver fibrosis from cirrhosis in patients infected with chronic hepatitis C genotype 1. Eur J Clin Microbiol Infect Dis. 2011;30:761-766.

40. Chen D, Liu JL, Liu Y, Zhu J, Wang SW. Lack of an association between $-308 \mathrm{G}>\mathrm{A}$ polymorphism of the TNF- $\alpha$ gene and liver cirrhosis risk based on ameta-analysis. Genet Mol Res. 2011; 10:2765-2774. 
41. Abbas Z, Moatter T, Hussainy A, Jafri W. Effect of cytokine gene polymorphism on histological activity index, viral load and response to treatment inpatients with chronic hepatitis $C$ genotype 3. World J Gastroenterol. 2005;11:6656-6661.

42. Akyüz F, Polat N, Kaymakoglu S, Aksoy N, Demir K, Beşişik F, Badur S, Cakaloglu Y, Okten A. Intrahepatic and peripheral T-cell responses in genotype $1 \mathrm{~b}$ hepatitis $C$ virus-infected patients with persistently normal and elevated aminotransferase levels. World J Gastroenterol. 2005;11:7188-7191.

43. Dubuisson J, Cosset FL. Virology and cell biology of the hepatitis C virus life cycle - An update. J Hepatol 2014;61(Suppl 1):3-13.
44. Mengshol JA, Golden-Mason L, Rosen HR. Mechanisms of Disease: HCV-induced liver injury. Nat Clin Pract Gastroenterol Hepatol. 2007;4:622-634.

45. Hiramatsu N, Hayashi N, Katayama K, Mochizuki K, Kawanishi Y, Kasahara A, Fusamoto H, Kamada T. Immunohistochemical detection of Fas antigen in liver tissue of patients with chronic hepatitis C. Hepatology. 1994;19:1354-1359.

46. Shahid M, Idrees M, Nasir B, Raja AJ, Raza SM, Amin I, et al. Correlation of biochemical markers and HCV RNA titers with fibrosis stages and grades in chronic HCV-3a patients. Eur $\mathrm{J}$ Gastroenterol Hepatol. 2014;26(7):788-94. 